\title{
ÜSTSÖYLEM: TANIM, MODELLER, ÇÖZÜMLEMELER ÇERÇEVESINDE BiR DEĞERLENDIRME
}

\author{
Metadiscourse: A Review of Definitions, Models and Analyses
}

\section{Ekin ŞEN ${ }^{*}$}

\section{öz}

Üstsöylem, alanyazında üreticinin (yazarın ya da konuşucu) metnin alıcısı (okur ya da dinleyici) tarafından nasıl anlaşılacağına yönelik gösterdiği yol, önermesel içeriğe herhangi bir katkı sağlamayan ancak içerikteki bilgiyi alıcının anlama, yorumlama ve değerlendirme gibi süreçlerine katkı sağlayan dilsel özellikler biçiminde tanımlanmaktadır. Buna göre önermesel ve üstsöylemsel anlamın toplamı olarak ele alınabilecek metinde, üreticinin bilgiyi düzenlemek için uyguladığı stratejiler, metindeki önermelere karşı duruşu ve metnin alıcısıyla girdiği etkileşim üstsöylem çalışmalarının temelini oluşturmaktadır. Bu çalışmada üstsöylem kavramının ne olduğunun ortaya konması amaçlanmıştır. Bu amaç doğrultusunda alanyazında yapılan üstsöylem tanımları, üstsöylemin özellikleri, üstsöylemin metin içinde üstlendiği işlevler üzerinde durulmuştur. Bunun yanı sıra alanyazındaki üstsöylem modelleri, bu modellerdeki sınıflandırmalar ve alanyazında en sık kullanılan kişilerarası üstsöylem modelindeki ulamlar, üstsöyleme bakış açısı ve altulamların özellikleri ayrıntılı biçimde tanıtılmıştır. Bundan sonra ise Türkçe alanyazında Türkçe üzerine yapılan üstsöylem çalışmalarının özellikleri ve gösterdikleri yönelim açıklanmış, genel olarak üstsöylem çözümlemelerinde ortaya çıkan birtakım sorunlar ve belirsizlikler değerlendirilmiştir.

Anahtar Sözcükler: üstsöylem, etkileşim, metin, yazar, okur.

\section{ABSTRACT}

Metadiscourse is defined in the literature as the way that the producer (writer or speaker) of the text shows how it will be understood by the receivers (reader or listener), as linguistic features that do not contribute to the propositional content but contribute to the processes such understanding, interpreting and evaluating the information in the content. Texts can be considered as the combination of propositional and metadiscourse meanings. The producers arrangement of the information in the text, his or her stance against the propositions in the text and his or her interaction with the receiver of the text form the basis of metadiscourse studies. The aim

\footnotetext{
* Dr., Duisburg-Essen Üniversitesi, Türkistik Enstitüsü, Essen/Almanya. E-posta: ekin.sen@unidue.de. ORCID ID: 0000-0003-4847-1840.
} 
of this paper is to determine the concept of the metadiscourse. In accordance with this purpose definitions and features of metadiscourse and functions of metadiscourse in the text have been explained, metadiscourse models in the literature and categorization of metadiscourse models have been explained. In addition, categories and subcategories of metadiscourse and their features, perspective on metadiscourse in the context of the interpersonal model, which is most frequently used in the literature, have been introduced. Thereafter, metadiscourse studies on Turkish have been introduced and some problems and fuzziness in metadiscourse analyses evaluated.

Keywords: metadiscourse, interaction, text, writer, reader.

\section{Giriş}

Bu çalışmada yaklaşık 40 yıldır dilbilim, dil eğitimi, yabancı dil öğretimi, yazma öğretimi, akademik yazma, söylem çözümlemesi gibi alanların çalışma kapsamında yer alan "üstsöylem" (metadiscourse) kavramıyla ilgili tanımların, işlevlerin, sınıflandırmaların ve çözümlemelerin tanıtılması amaçlanmıştır. Bu amaç doğrultusunda öncelikle üstsöylem kavramı tanıtılmış, metnin önermesel ve üstsöylemsel özellikleriyle metinsel ve kişilerarası işlevlere değinilmiş, Williams (1981, 1982), Crismore (1983), Vande Kopple (1985), Crismore vd. (1993), Hyland $(1998,2005)$ üstsöylem modellerinin özellikleri açıklanmış, bu modeller arasında alanyazında en sık kullanılan model olan Hyland (2005) Kişilerarası Üstsöylem Modeli'nin ulamları ayrıntılandırılmış, Türkiye'deki üstsöylem çalışmalarının hangi yönde olduğu üzerinde durulmuş ve üstsöylem çözümlemelerine yönelik eleştirilere değinilmiştir.

\section{1. Üstsöylem Kavramı}

Üstsöylem kavramını ilk kez kullanan Zellig Harris bu kavramla metin üreticisinin (yazılı metinlerde yazar, sözlü metinler konuşucu), dili alıcının (yazılı metinlerde okur, sözlü metinlerde dinleyici) anlamlandırması için gösterdiği yol biçiminde tanımlamaktadır (akt. Hyland, 2005: 3; 2017: 17). Daha sonraki çalışmalarda da üstsöylem benzer biçimlerde tanımlanmıştır. Buna göre Williams (2013: 58) konuyla ilişkili olmayan, ancak yazarın kendine, okuruna ya da metnine gönderde bulunan özellikler, Hyland (1998a: 438) metnin düzenlenişini ya da yazarın içeriğe ya da okura yönelik duruşunu yansıtan görünümler, Zeyrek (2002: 227) metinlerdeki değişimleri yansıtan farklı dilsel yapılarda olabilen birimler, Uzun (2002: 206-207) yazarın iletişimi kolaylaştırma, kendi konumunu gösterme ve destekleme, alıcıyla bağlantı oluşturma gibi amaçlarla kullandığı ve metnin temel belirleyicile- 
rinden biri, Bayyurt (2017: 15) ise içeriğin metni anlamaya yardımcı olacak biçime getirilmesine olanak sağlayan işlevler olarak tanımlar. Sözü geçen tüm üstsöylem tanımlarını kapsayıcı ve geliştirici nitelikteki bir tanımlamayı Crismore vd. (1993: 40) yapmıştır. Araştırmacılara göre üstsöylem kavramı söylemin tutarlı bir bütün olarak, yazar(lar)ın kişiliğini, okur gözündeki güvenilirliğini, sözlü ya da yazılı metinlerdeki önermesel içeriğe (propositional content) herhangi bir katkı sağlamayan ancak içerikteki bilgiyi alıcının anlama, yorumlama ve değerlendirme gibi süreçlerine katkı sağlayan dilsel özelliklerdir.

Üstsöylem, metnin yazarının ya da konuşucusunun söylediği şeyi alıcının anlamlandırabilmesi için en verimli katkının nasıl yapılabileceğine odaklanır. Buna göre üstsöylem iletinin en anlaşılır, açıklayıcı ve ayrıntılı biçimde ortaya çıkarılmasına, yazarın metni bir bağlamla ilişkilendirmesine, yazar kimliğini ortaya koymasına, okurla ve iletiyle ilişkini yansıtmasına yardımcı olan alıcı odaklı bir filtre görevi görür. Bu filtre kapsamında üstsöylem okurların ayrıntılandırma, rehberlik, açıklığa kavuşturma ve etkileşim gereksinimlerini de karşılar (Hyland, 2017: 17).

Yukarıda verilen ve alanyazında daha birçok araştırmacı tarafından da tanımlanan üstsöylemle ilgili olarak bir metinde hangi dilsel birimin üstsöylem kabul edilebileceği ya da edilemeyeceği gibi bir soru ortaya atılabilir. Swales (1993: 188) de bu tür bir sorudan hareketle üstsöylemin kavramsal olarak kabul edilmesinin kolay olduğuna, ancak uygulamada kavramın sınırlarını belirlemenin oldukça zor olduğunu belirtir. Dolayısıyla üstsöylemin ne olduğunun somut biçimde ortaya konması için alanyazında da sık sık üzerinde durulan ve Crismore vd.'nin tanımlamasında da dikkat çektiği bir ayrımdan söz etmek olasıdır. Bu ayrım, dilin hem dünyaya hem de kendisine gönderimde bulunan olgu olması arasındaki ayrımdır. Bir başka deyişle yukarıda da söz edilen önermesel içerik ya da "önermesel anlam" (propositional meaning) ve üstsöylemsel içerik ya da "üstsöylemsel anlam" (metadiscourse meaning) ayrımıdır (Hyland ve Tse, 2004: 159-161; Hyland, 2005: 38-41). Bu anlam düzeyleri arasındaki ayrım, önermesel anlamın okura bilgi sağladığı, üstsöylemsel anlamın ise metin oluşturma edimine gönderimde bulunduğu bir ayrımdır (Crismore, 1983: 2; Vande Kopple, 1985: 83; Hyland, 1998a: 438).

Birinci anlam düzeyi olan önermesel anlam düzeyinde ilgili metnin konusu hakkında bilgiler verilir ve önermesel içeriğin genişletilmesi sağlanır. Halliday (2004: 110) önermesel özelliğin üzerinde tartışılabilen, onaylanabilen, karşı çıkılabilen, şüphelenilebilen, nitelendirilebilen, ona karşı tutum 
sergilenebilen şey olduğunu belirtir. Dolayısıyla önerme, dış gerçekliğe ya da başka bir ifadeyle dünya gerçekliğine ilişkin bilgiye gönderimde bulunur.

ikinci anlam düzeyi olan üstsöylem düzeyinde önermesel içeriğe herhangi bir ekleme olmadan metni okuyacak ya da dinleyecek olanlara metinle ilgili düzenleme, sınıflandırma, yorum yapma, değerlendirme yapma ve tepki verme yönünde yardım söz konusudur. Benzer biçimde Vande Kopple (2012: 37) de göndergesel anlam dışındaki anlamları taşıyan metin ögelerinin üstsöylem olduğuna dikkat çeker. Metnin anlamlandırma süreci yalnızca önermesel anlama ya da yalnızca üstsöylem anlamına göre gerçekleştirilemez. Metnin anlamı, metindeki bilgisel içerikle yazarın metinde yansıttığı tutumu, duruşu, metin bölümleri arasında ortaya koyduğu bağlantı sonucu ortaya çıkar. Buradan hareketle metnin önermesel ögeler ile üstsöylem ögelerinin toplamı olduğu söylenebilir. Hyland (2005: 23) de üstsöylemin bir metnin temel parçası olduğunu ve metnin nasıl anlaşılacağına destek verdiği için metinden ayrı ya da metinden ayrıştırılabilir biçimsel ögeler olarak düşünülemeyeceğini belirtir. Dolayısıyla alıcının metni kavramsallaştırması, yazarın ise alıcılarla etkili bir iletişim kurabilmesi üstsöylem olmadan olası değildir (Hyland, 2005: 14). Hyland'a (2005: 44) göre önermesel bilgi ile üstsöylem bir metni oluşturan iki temel birimdir ve bu iki temel birim ve metinsel işlevleri aşağıdaki şekilde gösterilmektedir:

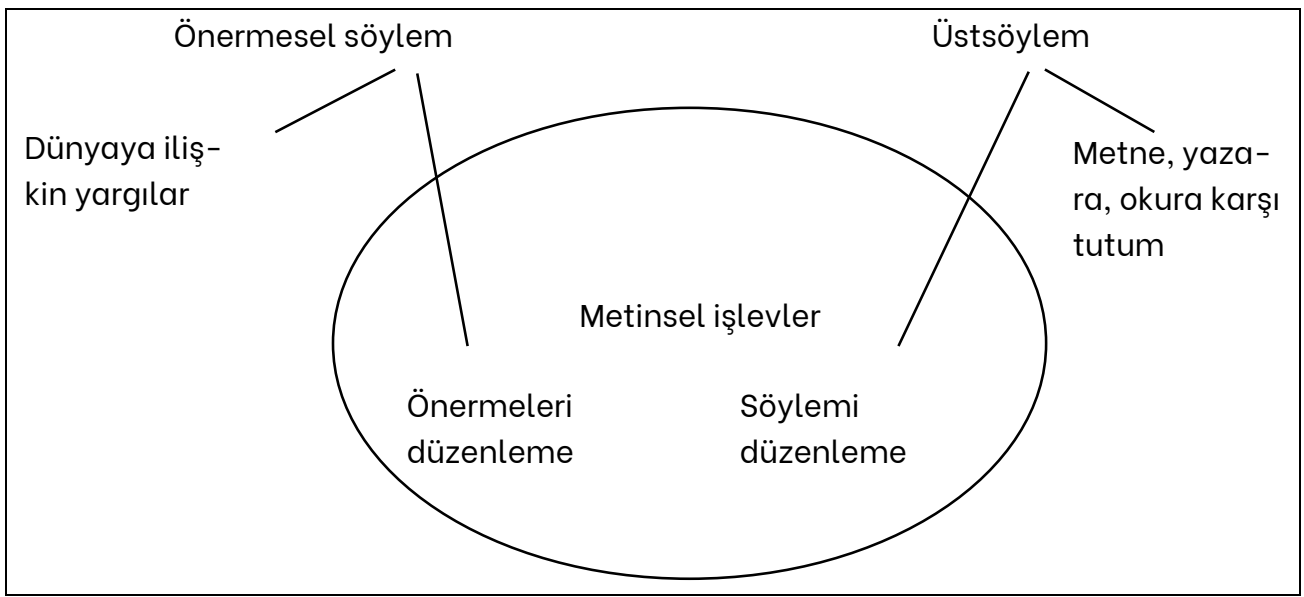

Şekil 1. Metinsel Araçların Metinde Üstlendiği Roller (Hyland, 2005: 44).

Şekil 1'de de görüldüğü üzere metin, dünyaya gönderimde bulunan, buna uygun olarak önermeleri düzenleyen önermesel söylemin ve metne, yazara, okura karşı tutumu belirten, genel olarak söylemi düzenleme amacını güden, önermelerin birbirleriyle, yazarın metinle ve yazarın okurla ilişkisini yansıtan üstsöylemden oluşur. Metnin, önermesel anlam ve üstsöylem- 
sel anlamın toplamı olduğu daha önce de belirtildiği üzere alanyazında kabul edilen bir görüştür. Üstsöylem ve önerme ilişkisini daha da somut bir biçime getirmek için Türkçe bir örnek vermek yararlı olabilir. Şu örnekler önerme içeriği ve önerme dışında kalan birimler bağlamında incelenebilir: 1. "Dünya güneşin etrafında döner" 2. "Sizin de bildiğiniz gibi Kopernik 1543 yılındaki çalışmasında dünyanın güneşin etrafında döndüğünü kesin olarak ortaya koymuştur."

Bu örnekler incelendiğinde ilk örnekte salt önerme içeriği görülmektedir. îkinci örnek incelendiğinde ise ilk örnekteki önerme içeriğinin korunduğu, ancak metne eklenen birtakım başka ögeler bulunduğu görülmektedir. Buna göre "dünyanın güneşin etrafında dönmesi" önermesine eklenen "sizin de bildiğiniz gibi", "Kopernik 1543 yılındaki çalışmasında", "kesin olarak" ve eyleme eklenen " $\{-\mathrm{mlşt|r}\}$ " ifadeleri önerme içeriğine herhangi bir eklenti yapmadan yazarın metnine ve okuruna yönelik etkileşimini yansıtmaktadır. Buna göre ilk eklenti (sizin de bildiğiniz gibi) yazarın doğrudan okurlarına seslendiği, onlardan gelebilecek olası karşı çıkışları engelleyen, ikinci eklenti (Kopernik 1543 yılındaki çalışmasında) ilgili önermenin kaynağını, dolayısıyla sorumlusunu yansıtan, üçüncü ve dördüncü eklenti (kesin olarak ve \{mlştır\}) de önerme içeriğindeki bilginin kesinliğini vurgulayan işlevler üstlenmektedir. Dolayısıyla bu üstsöylemsel ögeler önerme içeriğiyle bütünleşerek metni oluşturmaktadır.

Üstsöylem modelleri ve çalışmaları kuramsal temellerini Halliday'ın Dizgeci İşlevsel Dilbilgisi'ne dayandırır. Dizgeci iş̧levsel Dilbilgisi'ne göre dilin üç temel üstişlevi vardır: "düşünsel" (ideational), "kişilerarası" (interpersonal) ve "metinsel" (textual) işlevler. Düşünsel işlev düşünce ve deneyimleri betimlemek için kullanılan, önermesel içerikle eşdeğer olan işlevdir. Kişilerarası işlev etkileşimi kodlamak için dil kullanımına dikkat çeken, roller üstlenmeyi, değerlendirme yapmayı, duyguları anlamayı ve ifade etmeyi sağlayan işlevdir. Metinsel işlev ise dilin metni düzenlemek için kullanımına gönderimde bulunur. Dünyaya ve okurla/dinleyiciyle ilgili söylenenleri tutarlı biçimde düzenlemeyi sağlar (Halliday, 2004: 29-31).

Bir metnin anlamı dilin yukarıda belirtilen düşünsel, kişilerarası ve metinsel işlevlerinin bütünleşmesi ve her birinin diğeriyle ilişkisi sonucu ortaya çıkar. Burada daha önce de belirtilen anlam düzeylerine dönülecek olursa metnin önermesel ve üstsöylemsel anlam düzeylerinin birleşimi olduğu savı dilin işlevlerinde de görülmektedir. Burada dilin düşünsel üstişlevi metindeki önermesel anlam düzeyiyle, kişilerarası ve metinsel üstişlevleri de üstsöylemsel anlam düzeyiyle eşleşmektedir. Üstsöylem çerçevesinden bakıldı- 
ğında iki anlam düzeyi, Halliday'ın belirttiği dilin üstişlevlerinin eşzamanlı çalışmasına benzer bir biçimde çalışır ve birbirinden ayrılabilir değildir. Üstsöylem düzeyinin dilin kişilerarası ve metinsel üstişlevleriyle arasındaki ilişkiler, alanyazındaki üstsöylem modellerinin oluşturulmasında ve sınıflandırılmasında da kendini göstermektedir.

\section{2. Üstsöylem Modelleri}

Üstsöylem alanyazını incelendiğinde birçok araştırmacının üstsöylem konusunda çalışmaları olduğu ve Williams (1981, 1982), Crismore (1983), Vande Kopple (1985), Crismore vd. (1993), Hyland (1998a), Hyland (2005) gibi araştırmacılar tarafından çeşitli üstsöylem modellerinin geliştirildiği görülmektedir.

\subsection{Williams'ın (1981) Üstsöylem Modeli}

Williams'ın (1990) üstsöylem modelinde yazarın bir sav hakkındaki durumunu belirten "kaçınmalar" (hedges) ve "güçlendiriciler" (emphatics), metnin tutarlığını sağlamak için kullanılan "dizimleyiciler" (sequencers), metnin bir birimine dikkat çeken "konulaştırıcılar" (topicalizers), yazarın düşüncesini yansıtan "anlatıcılar" (narrators) ve yazarın dolaylı konuma geçtiği "kaynak göstericiler" (attributors) yer alır. Bu model üstsöylem alanyazında karşılaşılan ilk sınıflandırmadır.

\begin{tabular}{|l|l|}
\hline Üstsöylem Ulamı & Işlev \\
\hline Kaçınmalar & Bir savla ilgili belirsizliği yansıtma \\
\hline Güçlendiriciler & Bir savla ilgili kesinliği yansıtma \\
\hline Dizimleyiciler & Metin tutarlılığını, bir bölümden diğerine geçiş \\
\hline Konulaştırıcılar & $\begin{array}{l}\text { Tümce, paragraf ya da bölümün konusu gibi özel bir birime } \\
\text { dikkat çekme }\end{array}$ \\
\hline Anlatıcılar & $\begin{array}{l}\text { Okurlara yazarın düşüncesinin, gerçekliğinin nereden geldiğini } \\
\text { bildirme }\end{array}$ \\
\hline Kaynak göstericiler & $\begin{array}{l}\text { Belirsiz gözlemci, görüş/düşüncelerin dolaylı olarak söylemin } \\
\text { içine alınması }\end{array}$ \\
\hline
\end{tabular}

Tablo 1. Williams'ın (1981) Üstsöylem Sınıflandırması ${ }^{1}$

\footnotetext{
${ }^{1}$ Williams'ın ilgili kaynağının ilk baskısı 1981 yılındadır ve üstsöylem sınıflandırması için bu kaynağa gönderimde bulunulmaktadır. Bu makalede çalışmanın 1981 yılındaki baskısına ulaşılamamış, ilgili kaynağın 1990 yılındaki baskısına başvurulmuştur. Williams'ın çalışması incelendiğinde bu türden bir tablolaştırma yapmadığı görülmektedir. Hatta ilgili ulamlar metnin farklı sayfalarında açıklanmıştır. Bu çalışmada üstsöylem tablosu daha bütüncül görünmesi açısından Crismore (1983: 7-8) tarafından bir araya getirilen ulamlardan esinlenilerek oluşturulmuştur.
} 


\subsection{Williams'In (1982) Üstsöylem Modeli}

Williams (1982), 1981 yılında yaptığı ve altı ulamdan² oluşan üstsöylem sınıflandırmasını üç temel ulam altında toplayarak yeni bir sınıflandırma yapmıştır. Önceki sınıflandırmaya göre daha genel ulamlar içeren bu modelde "üstdüzenleyiciler" (advance organizers), "birleştiriciler" (connectives) ve "kişilerarası söylem" (interpersonal discourse) ulamları yer almaktadır. Bu model yazarın metindeki önermesel içeriğe karşı tutumunu yansıtan özellikleri alanyazına kazandıran ilk modeldir. Modeldeki kişilerarası söylem yazarın önermeye karşı nasıl bir yaklaşım içinde olduğunu gösteren dilsel ifadeleri barındıır (Crismore, 1983: 10-11).

\begin{tabular}{|l|l|}
\hline Üstsöylem Ulamı & işlev \\
\hline Üst düzenleyiciler & Başlangıcı, sonucu ya da özeti veren ifadeler \\
\hline Birleştiriciler & İçerikteki ilişkilerin yapısını belirtme \\
\hline Kişilerarası söylem & Yazarın duruşunu okura iletme \\
\hline
\end{tabular}

Tablo 2. Williams'ın (1982) Üstsöylem Sınıflandırması ${ }^{3}$

\subsection{Crismore'nin (1983) Üstsöylem Modeli}

Crismore (1983), oluşturduğu üstsöylem modelinde iki temel ulam oluşturmuştur: "bilgisel" (informational) ve "tutumsal" (attitudinal) üstsöylem. Bilgisel ulam altında yazar açık ya da örtük biçimde söylem hedefini, konuyu, konuyu düzenlemeyi, konuyla ilgili savını, kullanmayı planladığı sırayı, söylem tipini yansıtabilir. Tutumsal üstsöylem ulamı altında ise yazar açık ya da örtük biçimde söylemin yapısına, içeriğine ya da okura karşı tutumunu yansitabilir.

\begin{tabular}{|l|l|}
\hline Üstsöylem Ulamı & işlev \\
\hline \multicolumn{2}{|l|}{ Bilgisel üstsöylem } \\
\hline Hedefler & Genel amaç durumunu yansıtma \\
\hline Ön planlar & İçerik ve yapıyla ilgili birincil önem durumlarını gösterme \\
\hline Son planlar & İçerik ve yapıyla ilgili genel bilgiyi gösterme \\
\hline Konulaştırıcılar & Konuyu düzenleme \\
\hline Tutumsal üstsöylem & \multicolumn{2}{|l|}{} \\
\hline Belirginlik & Düşüncenin önemini belirtme \\
\hline Güçlendiriciler & Savın kesinliğini belirtme \\
\hline Kaçınmalar & Savın belirsizliğini belirtme \\
\hline Değerlendirici & İçeriğe ya da gerçekliğe karşı tutumu belirtme \\
\hline
\end{tabular}

Tablo 3. Crismore'nin (1983: 11-14) Üstsöylem Sınıflandırması

\footnotetext{
${ }^{2}$ Kaçınma, güçlendirici, dizimleyici, konulaştırıcı, anlatıcı ve kaynak gösterici.

${ }^{3}$ Çalışmada Williams (1982) kaynağına ulaşıtmamıştır. Bu nedenle Crismore'nin (1983) aktardığı sınıflandırma buraya alınmıştır.
} 


\subsection{Vande Kopple'nin (1985) Üstsöylem Modeli}

Alanyazında Hyland'ın (2005) oluşturduğu üstsöylem modeline kadar devam edecek ve üzerinde uzlaşım sağlanan iki ulam Vande Kopple (1985) tarafından oluşturulan üstsöylem modelinde görülmektedir. Araştırmacı üstsöylem ulamlarını Halliday'ın (2004) dilin üstişlevlerindeki adlandırmalarla, "metinsel" (textual) ve "kişilerarası" (interpersonal) üstsöylem biçiminde ikiye ayırmıştır.

\begin{tabular}{|c|c|}
\hline Üstsöylem Ulamı & işlev \\
\hline \multicolumn{2}{|l|}{ Metinsel Üstsöylem } \\
\hline Metin bağlayıcıları & $\begin{array}{l}\text { Okura, yazarın metni nasıl düzenlediği konusunda ve } \\
\text { metnin birimlerinin diğer birimlere nasıl bağladığı konu- } \\
\text { sunda bir farkındalık kazandırmaya yardımcı olma }\end{array}$ \\
\hline Açımlayıcılar & $\begin{array}{l}\text { Metindeki birimlerin uygun biçimde anlaşılmasında okura } \\
\text { yardım etme }\end{array}$ \\
\hline Geçerlilik belirleyicileri & $\begin{array}{l}\text { Önermesel içeriğin olasılığı ya da kesinliğine yönelik de- } \\
\text { ğerlendirmeyi anlatma }\end{array}$ \\
\hline Anlatıcılar & $\begin{array}{l}\text { Bir düşüncenin biri tarafından söylendiğini okurlara bil- } \\
\text { dirme }\end{array}$ \\
\hline \multicolumn{2}{|l|}{ Kişilerarası Üstsöylem } \\
\hline Edimsöz belirleyicileri & $\begin{array}{l}\text { Yazarın okurları için metindeki bir şeyi daha açık ve net } \\
\text { yapma isteğini belirtme }\end{array}$ \\
\hline Tutum belirleyicileri & Önermesel içeriğe karşı tutumu ortaya koyma \\
\hline Yorumlar & $\begin{array}{l}\text { Okuru doğrudan yönlendirme ve genellikle okuru bir söy- } \\
\text { leșimin içine çekme }\end{array}$ \\
\hline
\end{tabular}

Tablo 4. Vande Kopple'nin (1985) Üstsöylem Sınıflandırması ${ }^{4}$

Metinsel üstsöylem altında yazarın okura rehberlik etmesi, düşünce biçimini yansıtması, metinde bir birimin bir diğer birime hangi açıdan, ne türden bir ilişkiyle bağlandığının belirtilmesi, okurun zihninde uygun temsillerin oluşturulması, bir sözcüğün, öbeğin ya da ifadenin açıklanması gereksiniminin karşılanması, yazarın ifade ettiği önermenin içeriğinin kesinlik ya da olasılığına yönelik ne türden bir değerlendirme yaptığının belirtilmesi, bir düşüncenin kime ait olduğunun açıkça ortaya konması söz konusudur. Kişilerarası üstsöylemde ise yazarın bir şeyi daha açık ve net olarak göstermesi, yazarın sunduğu önermesel içeriğe karşı tutumunu, bakış açısını, tepkisini vb. yansıtmasına yöneliktir.

\footnotetext{
${ }^{4}$ Vande Kopple üstsöylem sınıflandırmasındaki ulamları tam olarak tablolaştırmamış, bunun yerine tüm ulamları alt alta sıralayarak açıklama yolunu seçmiştir. Bu ulamların tablolaştırılma biçimi Hyland'dan (2005: 32) alınmış olup modeldeki ulamların içeriği özgün çalışmadan (Vande Kopple, 1985) alınmıştır.
} 
Vande Kopple'nin (1985) üstsöylem modeli önceki modellerin bir devamı niteliğindedir. Buna göre Crismor'de (1983) yer alan ancak adlandırması farklı biçimde olan ulamlar (bilgisel ve tutumsal üstsöylem ulamları) metinsel ve kişilerarası biçimine dönüştürülmüş ve içeriklerinde de bazı düzenlemeler yapılmıştır. Bunun yanı sıra Williams (1981; 1982) modellerinde de karışık olarak verilen altulamların bu modelde genişletilerek ya da değiştirilerek yer aldığı söylenebilir. Buna koşut olarak Hyland'da (2005: 32) da Vande Kopple'nin yapmış olduğu bu sınıflandırmanın alanyazında birçok araştırmacı tarafından kullanıldığı belirtilmektedir.

\subsection{Crismore vd.'nin (1993) Üstsöylem Modeli}

Vande Kopple'nin 1985 yılında ortaya koyduğu ikili üstsöylem sınıflandırması daha sonraki modelleri de etkilemiştir. Crismore vd. (1993: 47-54), bu modeli örnek almış, modeldeki altulamları yeniden düzenleyerek aşağıdaki gibi bir modele ulaşmıştır:

\begin{tabular}{|l|l|}
\hline Ulam & Işlev \\
\hline Metinsel Üstsöylem \\
\hline 1.Metinsel belirleyiciler \\
\hline Mantıksal bağlayıcılar & Düşünceler arasındaki bağlantıları gösterme \\
\hline Dizimleyiciler & Materyalin düzenlemesi/dizimlenmesi \\
\hline Hatırlatıcılar & Daha önceki bir metin bölümüne gönderimde bulunma \\
\hline Konulaştırıcılar & Konuda gerçekleştirilen bir değişikliği yansıtma \\
\hline 2.Yorumsal belirleyiciler & \multicolumn{2}{|l}{} \\
\hline Açımlayıcılar & Metin bölümünün açıklama \\
\hline Edimsöz belirleyicileri & Yapılan eylemin adının verilmesi \\
\hline Bildirimler & Bir sonraki metin bölümünü bildirme \\
\hline Kişilerarası Üstsöylem & Bir savın doğruluğundaki belirsizlik durumunu gösterme \\
\hline Kaçınmalar & Savın kesinliğini ifade etme \\
\hline Kesinlik belirleyicileri & Bilginin kaynağını/desteğini verme \\
\hline Kaynak göstericiler & Yazarın duyusal değerlendirmesini yansıtma \\
\hline Tutum belirleyiciler & Okur ile ilişki kurma \\
\hline Yorum
\end{tabular}

Tablo 5. Crismore vd.'nin (1993: 47-54) Üstsöylem Sınıflandırması

Tablo 5’te de görüldüğü gibi Crismore vd. (1993), üstsöylem modelini "metinsel üstsöylem" (textual metadiscourse) ve "kişilerarası üstsöylem" (interpersonal metadiscourse) olmak üzere iki ulama ayrılmış olarak tasarlamıştır. Crismore vd. (1993) metinsel üstsöylemin altında bulunan altulamları iki grupta toplayarak Vande Kopple'den (1985) ayrılır. Araştırmacıların modelinde metinsel üstsöylem "metinsel belirleyiciler" (textual mar- 
kers) ve "yorumsal belirleyiciler"den (interpretive markers) oluşur. Metinsel belirleyiciler metin düzenlemesine yönelik metnin mantıksal, dizimsel, gönderimsel ve konu değişikliğine yönelik özelliklerini, yorumsal belirleyiciler ise ayrıntılandırma, edimsöz ve ilerleyen konuya gönderim özelliklerini yansıtır. Crismore vd.'nin (1993) üstsöylem modelindeki ikinci ulam kişilerarası üstsöylemdir ve bu ulam yazarın bilgiye karşı tutumuna ve okurlarıyla ilişkisine gönderimde bulunur. Vande Kopple'nin modelinde geçerlilik belirleyicileri olarak geçen altulam, bu modelde üçe ayrıştırılmıştır: "kaçınmalar" (hedges), "kesinlik belirleyicileri" (certainty markers), "kaynak göstericiler" (attributors). "Tutum belirleyiciler" (attitude markers) ve "yorum" (commentary) altulamları ise aynı biçimde korunmuştur.

\subsection{Hyland'ın (1998) Üstsöylem Modeli}

Hyland (1998a: 442) özellikle bilimsel makalelerin üstsöylem belirleyicilerinin kullanımı açısından incelenmesiyle önceki modellerin değiştirilmesi gerekliliğini, güncellenen yeni modelde bazı ulamların çıkarılması, bazılarının ise kapsamının daraltılması ile sözbilimsel işlevlerin daha iyi açıklanabileceğini öne sürmüş ve yeni bir üstsöylem modeli ortaya çıkarmıştır. Araştırmacı bu sınıflamanın hem metin tutarlıığı hem de söyleme katılanlar arasındaki etkileşimi vurgulayan biçimde, Vande Kopple'nin (1985) oluşturduğu modeldeki gibi metinsel üstsöylem ve kişilerarası üstsöylem düzlemleri olarak ikili bir yapıda olduğunu belirtir. Bu bağlamda Hyland'da (1998a) sunulan, özellikle akademik metinlerin incelenmesiyle oluşturulan üstsöylem modeli aşağıdaki gibidir.

\begin{tabular}{|c|c|}
\hline Küme & işlev \\
\hline \multicolumn{2}{|l|}{ Metinsel Üstsöylem } \\
\hline Mantıksal bağlayıcılar & Temel tümcelerdeki anlamsal ilişkileri tanımlama \\
\hline Çerçeve belirleyiciler & $\begin{array}{l}\text { Geçişlere ya da söylemsel edimlere gönderimde bulun- } \\
\text { ma }\end{array}$ \\
\hline Metiniçi belirleyiciler & $\begin{array}{l}\text { Metnin diğer bölümlerindeki bilgilere gönderimde bu- } \\
\text { lunma }\end{array}$ \\
\hline Tanitlayıcılar & Alıntılanan bilginin kaynağına gönderimde bulunma \\
\hline Açımlayıcılar & $\begin{array}{l}\text { Düşünsel malzemenin anlamının kavranmasına yardım } \\
\text { etme }\end{array}$ \\
\hline \multicolumn{2}{|l|}{ Kişilerarası Üstsöylem } \\
\hline Kaçınmalar & $\begin{array}{l}\text { Yazarın metnindeki ifadelerin tüm sorumluluğunu yük- } \\
\text { lenmemesi }\end{array}$ \\
\hline Vurgulayıcılar & $\begin{array}{l}\text { Yazarın iletisinin kesinliğinin ya da geçerlilik düzeyinin } \\
\text { vurgulanması }\end{array}$ \\
\hline Tutum belirleyiciler & Yazarın önermesel içeriğe yönelik tutumunun açıklan- \\
\hline
\end{tabular}




\begin{tabular}{|l|l|}
\hline & ması \\
\hline ilişki belirleyiciler & $\begin{array}{l}\text { Okura açık gönderimlerde bulunma ya da okurla açık } \\
\text { ilişkiler kurma }\end{array}$ \\
\hline Kişi belirleyiciler & Yazara açık gönderimler yapma \\
\hline
\end{tabular}

Tablo 6. Akademik Metinlerde Üstsöylemin Iş̧levleri5 (Hyland, 1998a).

Tablo 6'daki sınıflandırmada üstsöylem iki doğrultuda bir işlev üstlenir. ilk doğrultuda (metinsel üstsöylem) metin tutarlılı̆ı ön plana çıkarken ikinci doğrultuda (kişilerarası üstsöylem) yazar ile okur ya da konuşucu ile dinleyici gibi katılımcı etkileşimi ön plana çıkar (Hyland, 1998a: 442-443; Uzun, 2002: 208). Bu modelde Hyland'ın daha önceki modellerle hem benzer hem de farklı ulamlar oluşturduğu görülmektedir. Buna göre Crismore vd.'nin (1993) modelinde kişilerarası üstsöylemin altında konumlandırılan kaynak göstericiler yeni modelde metinsel üstsöylemin altına alınmış ve tanıtlayıcı biçimini almıştır. Alanyazındaki modellerde (Williams, 1981 ve 1982; Crismore, 1983; Vande Kopple, 1985; Crismore vd., 1993) yazarın kendini metin içinde açıkça göstermesini sağlayan herhangi bir ulam bulunmazken güncel modelin kişilerarası ulamı altına yazarın kendini metin içinde açıkça yansıtmasına gönderimde bulunan kişi belirleyicileri eklenmiştir. Ayrıca $\mathrm{Hy}-$ land daha önceki modellerde hatırlatıcı ve bildirimler olarak adlandırılan iki ulamı birleştirerek metin içi gönderim ulamını, bir önceki modelde yer alan edimsöz belirleyicilerini, dizimleyicileri ve konulaştırıcıları birleştirerek çerçeve belirleyiciler ulamını oluşturmuştur.

\subsection{Hyland'ın (2005) Üstsöylem Modeli}

Üstsöylem iletişimi kolaylaştırmada, yazar konumunu desteklemede, alıcıyla ilişki kurmada önemli kişilerarası araçlardan biri olarak kabul edilmektedir (Hyland ve Tse, 2004: 159; Hyland, 2015: 997). Bu, yazarın konuşarak ya da yazarak diğer kişilere karşı olası yanıtlarını yansıtma, dinleyici ya da okurlar üzerinde oluşturulan etkinin türüne karar verme ve amaçlara ulaşmak için kullanılan dili en iyi biçimde düzenleme yoludur. Hyland (2017: 19-20) alandaki araştırmacıların temel üstulam başlıklarında uzlaşıma varsalar da modellerindeki altulamlar konusunda karşıtlıklar görüldüğünü belirtir. Bu bakış açısından hareketle alandaki üstsöylem sınıflandırmalarının üstsöyleme iki farklı yönde bakış açısı geliştirdiği söylenebilir. Alanyazındaki modeller üstsöylemi ya metinsel ya da kişilerarası özelliklerini önce-

\footnotetext{
5 Türkçe alanyazın incelendiğinde Uzun'un (2002) bu sınıflandırmayı Türkçeye kazandırdığı görülmektedir. Bu bağlamda bu üstsöylem sınıflandırmasındaki terimlerin Türkçeleri Uzun'dan (2002: 209-210), modelle ilgili işlev ve açıklamalar özgün kaynak Hyland'dan (1998a: 442) alınmıştır.
} 
leyerek tanımlamış ve modellerini buna göre geliştirmiştir. Hyland (2017: 20), daha önceki üstsöylem sınıflandırmalarındaki bu iki bakış açısının yerine yeni bir bakış açısıyla oluşturduğu üstsöylem modelini önerir. Bu, Thompson'daki (2001) "bilgi odaklı etkileşimli" (interactive) ve "alıcı odaklı etkileşimli" (interactional) kaynaklar arasındaki ayrımdan uyarlanan ve ilk biçimi Hyland ve Tse'de (2004) geliştirilen, daha sonra Hyland'da (2005) son biçimini alan üstsöylem modelidir.

Üstsöylem terimi yazar-okur etkileşimini oluşturan metin görünüşlerine gönderimde bulunur. Bir başka deyişle üstsöylem başarılı bir iletişim için gerekli etkileşimleri oluşturan bir olgudur. Buradan hareketle üstsöylem alanyazınındaki egemen ayrım olan metinsel ve kişilerarası işlev ayrımını reddeden Hyland ve Tse (2004: 159) okurun bilgisini, metinsel deneyimlerini ve işlemleme gereksinimlerini göz önünde bulunduran ve bunu yerine getirebilmek için de yazara sözbilimsel başvuru olanağı sunan tüm üstsöylem özelliklerinin kişilerarası olduğunu savunur (Hyland ve Tse, 2004: 161). Araştırmacılar tüm üstsöylem ulamlarının kişilerarası olduğu yönünde bir sınıflama yapma nedenlerini metinsel üstsöylem belirleyici olarak adlandırılan bir birimin metin içinde farklı işlevlere de sahip olabildiği savıyla gerekçelendirmektedir. Sözgelimi bir üstsöylem belirleyicisini yalnızca metinsel üstsöylem belirleyici olarak sınıflandırılmak olası değildir. Çünkü metinsel bir işlem gerçekleştiren bir birim aynı zamanda okurlara oradaki bilginin nasıl anlaşılması gerektiğini de gösterir. Dolayısıyla kişilerarası etkileşime de katkı sağlar. Bu durumda daha önceki modellerde metinsel üstsöylem olarak ayrı bir ulam biçiminde gösterilen ulamın da metnin kişilerarası özelliklerinin bir görünümü olduğunu belirten Hyland (2005: 45) tüm üstsöylemin yazar ve okur arasındaki etkileşime işaret ettiğini, dolayısıyla da kişilerarası olduğunu belirtir. Bu bilgiler ışığında Hyland'ın (2005) oluşturduğu kişilerarası üstsöylem modeli aşağıdaki gibidir.

\begin{tabular}{|l|l|}
\hline Ulam & İşlev \\
\hline Bilgi Odaklı Etkileşimli & Okura metin içinde rehberlik etme \\
\hline Mantıksal bağlayıcılar & Tümceler arasındaki ilişkiyi ifade etme \\
\hline Çerçeve belirleyiciler & $\begin{array}{l}\text { Söylem edimlerine, dizilerine ya da evrelerine gönde- } \\
\text { rimde bulunma }\end{array}$ \\
\hline Metiniçi belirleyiciler & $\begin{array}{l}\text { Metnin diğer bölümlerindeki bilgiye gönderimde bulun- } \\
\text { ma }\end{array}$ \\
\hline Tanıtlayıcılar & Diğer metinlerdeki bilgilere gönderimde bulunma \\
\hline Açımlayıcılar & Önermesel anlamları ayrıntılandırma/genişletme \\
\hline Alıcı Odaklı Etkileşimli & Okuru metin içine dâhil etme \\
\hline
\end{tabular}




\begin{tabular}{|l|l|}
\hline Kaçınmalar & Sorumluluğu ve açık söyleşimleri sınırlandırma \\
\hline Vurgulayıcılar & Kesin ya da yakın söyleşimleri vurgulama \\
\hline Tutum belirleyicileri & Yazarın önermeye karşı tutumunu belirtme \\
\hline Kendinden sözetme & Yazarın açıkça kendisine gönderimde bulunma \\
\hline Katılım belirleyicileri & Okurla açıkça ilişki kurma \\
\hline
\end{tabular}

Tablo 7. Üstsöylemin Kişilerarası bir Modeli' (Hyland, 2005: 49).

\subsection{1. Üstsöylemin Bilgi Odaklı Etkileşimli Boyutu}

"Bilgi odaklı" ve "alıcı odaklı etkileşimli” olarak ikiye ayrılan üstsöylem modelinin ilk boyutu yazarın okurların bilincinde olduğu, okurların olası bilgisini, ilgilendiği konuları, beklentilerini ve yeterliliklerini düzenlemek için kullandığı yolları belirtir. Bu anlamda yazarın amacı okurun beklentilerine göre metnini biçimlendirmek ve savlarını oluşturmaktır. Bilgi odaklı etkileşimli kaynaklardaki altulamlar, söylemi düzenlemeyi ve okurun gereksinim duyduğu metinsel düzenleme biçimlerini kapsar. Hyland (2005: 50) bilgi odaklı etkileşimli kaynakların önermesel bilginin okurlar için tutarlı ve ikna edici biçimde düzenlenmesinde kullanıldığını belirtir. Bunlar okur için bir rehber görevi görür ve yazar-okur ilişkisinin oluşturulmasını sağlar. Bilgi odaklı etkileşimli üstsöylem altındaki belirleyiciler beş altulamda toplanır: "mantıksal bağlayıcılar" (transitions), "çerçeve belirleyiciler" (frame markers), "metiniçi belirleyiciler" (endophoric markers), "tanıtlayıcılar" (evidentials), "açımlayıcılar" (code glosses).

Mantıksal bağlayıcılar, okurun söylemin gelişimindeki adımlar arasında bulunan bağlantıları yorumlamasına yardımcı olan, metinde sunulan ekleme, sonuç, çıkarma ya da karşılaştırma gibi ilişkilerin ortaya konmasını sağlayan, dolayısıyla metnin anlaşılmasını kolaylaştıran ögelerdir (Hyland, 2005: 50; Uzun, 2006: 138; Khedri, Heng ve Ebrahimi, 2013: 322).

Çerçeve belirleyicileri, metnin şematik yapısındaki ögelere ya da metnin sınırlarına gönderimde bulunan metnin bölümlerini sıralama, metin bölümlerini işaretleme, savların yönünü belirtme, konu değişimlerini gösterme gibi ilişkileri açıkça belli eden ögelerdir. Bu ögeler metnin alıcısına metin boyunca ne yapıldığını ya da ne yapılacağını açıklar ve dolayısıyla metnin çizgisel olarak izlenebilmesine olanak sağlar (Hyland, 2005: 51; Uzun, 2006: 138; Hyland, 2010: 129; Khedri, Heng ve Ebrahimi, 2013: 323).

\footnotetext{
${ }^{6}$ Hyland'ın (2005) alanyazına kazandırdığı üstsöylem modelinin ilk biçimi Hyland ve Tse'nin çalışmasında (2004) yayımlanmıştır. iki model arasında herhangi bir farklılık olmaması ve altulamların Hyland (2005) Metadiscourse adlı çalışmada ayrıntılı biçimde açıklanması nedeniyle burada yalnızca Hyland'daki (2005) model alınmıştır.
} 
Metiniçi belirleyiciler metnin diğer bölümlerine gönderimde bulunan, ek bilgi sunarak okurun metni anlamasını kolaylaştıran, önceki ya da sonraki bilgiye gönderimde bulunarak tartışmayı destekleyen, yazarın okuru metin içinde açıkça yönlendirmesini destekleyen, metnin hem tek anlamlı okunmasına hem de çizgisel olarak izlenmesine olanak sağlayan dilsel ögelerdir (Hyland, 2005: 51; Uzun, 2006: 138; Khedri, Heng ve Ebrahimi, 2013: 323; Şenöz-Ayata, 2014: 46).

Başka bir kaynakta bulunana bilginin "üstdilsel" (metalinguistic) sunumu olarak tanımlanabilecek tanıtlayıcılar, metin dışındaki kaynaklardan alınan düşüncelerin güncel metne taşındığını kodlamak için kullanılan, bir konudaki sorumlunun kim olduğunu gösteren, okurun yorumunu yönlendirerek yazarın konuyla ilgili görüşlerini güçlendiren, dolayısıyla metnin kabul edilmesine destek olan ögelerdir (Thomas ve Hawes, 1994: 129; Hyland, 2005: 51; Fidan ve Cem-Değer, 2008: 188; Hyland, 2010: 129).

Bilgi odaklı etkileşimli üstsöylem altında yer alan son ulam, önermeyi ayrıntılandırarak ya da genişleterek ek bilgi sunan, yazarın niyetinin okur tarafından anlaşılmasını kolaylaştıran ve bilgiyi yeniden düzenleyerek ya da örneklendirerek metne yansıtılan açımlayıcılardır (Crismore vd., 1993: 49; Hyland, 2005: 52; Hyland, 2010: 129).

\subsection{2. Üstsöylemin Alıcı Odaklı Etkileşimli Boyutu}

Akademik metinler genellikle kişi bildirmeyen, nesnel, bilgilendirici ve gerçekliğin tanımlanması olarak düşünülür. Ancak akademik söylemin ikna ediciliği yalnızca kesin doğruluğun kanıtlanması, deneysel kanıtlar ya da kusursuz mantık aracılığıla sağlanmaz. Metinler toplumsal olarak konumlandırılmış yazarların eylemlerinin bir sonucudur ve ancak alandaki diğer uzmanların ikna edici bulduğu toplumsal ve dilsel uzlaşımlar işletildiğinde ikna edici olur (Hyland, 2014: 99). Yazarın önerme içeriğine karşı duruşunu, metne kendini yansıtmasını ve alıcıyı söylem katılımcısı olarak metne dâhil etmesini sağlayan ve Hyland'ın üstsöylem modelindeki ikinci boyut olan "alıcı odaklı etkileşimli" (interactional) üstsöylem yazarın etkileşime girme yollarını ortaya koyar. Yazarın buradaki amacı kendi bakış açısını da yansıtarak okurları metnin söyleminin içine çekmek ve onların gelişmekte olan metne tepki vermelerini sağlamaktır. Bu amaç doğrultusunda yapılan düzenlemeler yazarın önermesel bilgiye ve okura yönelik bakış açısını ortaya koyar. Üstsöylem bu noktada değerlendirici, bağlantı oluşturucu, olası karşı çıkmaları öngören ve olası bir söyleşime yanıt veren bir niteliğe bürünmektedir (Hyland, 2005: 49). Alıcı odaklı etkileşimli üstsöylem yazar-okur ilişki- 
sinin oluşturulmasında ve metnin okuması sırasında yazarın okur tarafından olası karşı çıkışlarını önlemesinde rol oynar (Uzun, 2006: 139). Bu üstsöylem belirleyicileri beş altulamda toplanır: "kaçınmalar" (hedges), "vurgulayıcılar" (boosters), "tutum belirleyicileri" (attitude markers), "kendinden sözetme" (self mention), "katılım belirleyicileri” (engagement markers).

Yazarın önermeye bağlılığını kısıtlayan, kesinliği yumuşatan, diğer olasılıkların varlığının yazar tarafından da tanındığını belirten kaçınma aynı zamanda yazarın kanıtlanmamış bir önermeyi kullandığını göstermek için de kullanılır (Hyland, 1998b: 50; 2005: 52; Uzun, 2006: 139; Bayyurt ve Akbaş, 2014: 74; Ayata, 2014: 42). Vurgulayıcılar yazarın önermeye kesin bir bağlılı̆ını belirten, görüş ayrılıklarının önüne geçen, yazarın kendini kuşkusuz hissettiği durumları yansıtan, önermenin gücünü arttıran, karşı çıkmaları engelleyen ögelerdir (Hyland, 1998c: 350; 2005: 52-53; 2008a: 7-8; Uzun, 2006: 139; Bayyurt ve Akbaş, 2014: 74).

Tutum belirleyicileri yazarın önermelere karşı bilginin durumundan çok onun olası güvenilirliğine, doğruluğuna karşı kabul etme/etmeme, önemini, gerekliliğini, kızgınlığını ya da uzlaşımını gösterme gibi duygusal tutumunu ifade eder (Crismore vd., 1993: 53; Hyland: 2005: 53, Uzun, 2006: 139). Tutum, yazarın olumlu-olumsuz duygularını, yazarın onayladığı, eleştirdiği, övdüğü ya da kınadığı davranışlara bakışını yansıtır ya da bir önermeye verilen değeri ortaya koyabilir (Martin ve White, 2005: 42-43).

Alanyazındaki birçok çalışma yazarların veri bütünlüğünü korurken okurlarla başarılı etkileşim kurmaya çalıştığını göstermektedir. Bu bağlamda yazarın okurla etkileşim kurma yollarından birisi de kendini metin içinde açıkça kodlamasıdır (Hyland, 2001: 207-208). Yazarlar kendi izlenimlerini ve savlarıyla, alanlarıyla, okurlarıyla ilişkilerindeki duruşlarını metne yansıtmak isteyebilirler. Dilsel seçimler yapan yazarlar ifade ettikleri kavramsal ya da düşünsel anlamı etkilemekle kalmaz, aynı zamanda okurlarında yarattıkları izlenimi de etkileyebilmek isterler. Kişi bildirmeyen bir biçemi benimseme ya da kendini açıkça yansıtma kararı okurun iletiyi nasıl alacağına ilişkin sonuçları belirler (Hyland, 2001: 210-211). Bu kapsamda yazarın metin içinde kendini açıkça kodlaması, sorumluluğu doğrudan üstüne alması kendinden söz etme üstsöylem belirleyicileri ile gerçekleşir.

Katıım belirleyicileri, metinde açık biçimde okura seslenme, onun dikkatini çekme ya da onu söylem katılımcısı olarak metne dahil etme işlevini yerine getirir. Bu tür bir strateji yazarın okurlarını ikna etme, onların olası 
sorularının önüne geçme gibi amaçlar taşır (Hyland, 2005: 53-54; 2008b: 9).

Alanyazındaki üstsöylem modellerine genel olarak bakıldığında 1981'den 2005'e kadar modellerin gereksinimlere, yapılan çözümlemelere, farklı türlerin çözümlemelere dâhil edilmesine bağlı olarak modellerin birtakım farklılıklar gösterdiği anlaşılmaktadır. Hyland (2005)'ın alanyazına kazandırdığı son model özelinde ise altulamların Crismore ve Vande Kopple'nin çalışmalarındakine benzer olarak görüldüğü, adlandırmaların o modellerden alındığı ancak bu altulamların kişilerarası boyutu vurgulaması bağlamında kavramsal olarak onlardan çok farklı olduğunu söylenebilir (Hyland, 2010: 130). Buradan hareketle Hyland'ın bilgi odaklı etkileşimli ve alıcı odaklı etkileşimli üstsöylem ulamları ve bu ulamlara bağlı altulamlarla ile ilgili açıklamalarından anlaşılacağı üzere her iki ulam da kişilerarası bir görünüm sergilemektedir. Metne yapılan her türden önermesel olmayan eklenti, başka bir ifadeyle üstsöylem eklentisi, yazarın okuru yönlendirme, onunla doğrudan ya da dolaylı yollarla etkileşime girme, onun beklentilerine göre bir metin oluşturma gibi kişilerarası işlevler üstlenmektedir.

\section{Türkçede Üstsöylem Çalışmaları}

Türkçe alanyazın üstsöylem çerçevesinde incelediğinde birçok çalışmayla karşılaşılmaktadır. Türkçede üstsöylemle ilgili karşılaşılan ilk çalışmalar dilbilim makalelerindeki üstsöylem belirleyicilerini inceleyen Uzun (2002) ve psikoloji makalelerindeki üstsöylem belirleyicilerini inceleyen Zeyrek'tir (2002). Bunun yanı sıra söylem topluluğunun bilimsel metinlerden beklentilerini ve beklentilere göre metindeki üstsöylem düzenlemelerini inceleyen Uzun (2006); iki dilli bireylerin vurgulayıcı ve kaçınma belirleyicilerini algılama durum ve uygulamalarını araştıran Bayyurt ve Akbaş (2014); Türkçe eğitimi ve Türk dili ve edebiyatı makalelerinde kullanılan üstsöylem belirleyicilerini karşılaştıran Kan (2016); üstsöylem belirleyicilerinin kullanımını Türkçe eğitimi bağlamında araştıran Sarar-Kuzu (2016); üstsöylem ile kültür etkileşimini inceleyen Bayyurt (2017), Türkçeyi yabancı dil olarak öğrenen bireylerin metinlerindeki üstsöylem belirleyicilerini inceleyen Çubukçu (2017), bilgi odaklı etkileşimli üstsöylem belirleyicilerinin makalelerdeki kullanımını inceleyen Dağ-Tarcan (2017), anadil konuşucuları tarafından üretilen kanıtlayıcı metinlerdeki kaçınma ifadelerini inceleyen Hatipoğlu ve Algı (2017), anadil konuşucuları tarafından oluşturulan neden bildiren paragraflardaki neden belirleyicilerini inceleyen Uluçay ve Hatipoğlu (2017); iki dilli öğrenciler tarafından üretilen metinlerde kullanılan alıcı odaklı etkileşimli üstsöylem belirleyicilerini inceleyen Uluçam-Wegmann 
(2018); yabancı dil olarak Türkçe öğrenenlerin ikna metinlerindeki üstsöylem belirleyicilerini inceleyen Esmer (2018); fen ve sosyal bilimler makale özetlerindeki üstsöylem belirleyicilerini inceleyen Şen (2019); sosyal bilimlerdeki bilimsel metinlerde üstsöylem kullanımı inceleyen Dağ-Tarcan (2019); Türkçe eğitimi alanındaki yüksek lisans tezlerindeki üstsöylem belirleyicilerini inceleyen Önel (2020); Türkçeyi yabancı dil olarak öğrenen öğrencilerin oluşturdukları akademik metinlerde üstsöylem belirleyicilerini inceleyen Kurudayıoğlu ve Çimen (2020) biyoloji ve dilbilim makale özetlerindeki birinci tekil ve çoğul kişi adılını üstsöylemsel özellikler çerçevesinde inceleyen Şen (2020) biçimindedir.

Türkçe alanyazında Türkçe ile ilgili üstsöylem çalışmaları incelendiğinde araştırmacıların genellikle bilimsel metinlerdeki belirleyicileri (tez, makale gibi) ve öğrenciler tarafından oluşturulan akademik yazma çerçevesinde değerlendirilebilecek (bilgilendirici, ikna edici metinler) metinlerdeki üstsöylem belirleyicilerini inceleme yönünde bir eğilim gösterdikleri söylenebilir. Dolayısıyla Türkçe alanyazındaki çalışmaların üretilmiş metinlerdeki üstsöylem belirleyicilerini ortaya koyan çalışmalar olduğu görülmektedir. Bu çalışmalarda metin türü ya da metin üreticisi bağlamında ne türden üstsöylemsel eğilimlerin bulunduğu saptanmıştır. Ancak yapılan çalışmaların büyük bölümünde saptanan üstsöylem belirleyicilerinin listesine yer verilmemiştir. Bu bağlamda çalışmalarda saptanan belirleyicilerin ve bu belirleyicilerin sınıflandırılmasının nasıl yapıldığı bilinememektedir. Uluslararası alanyazın incelendiğinde ve Türkçe alanyazınla karşılaştırıldığında anadili eğitimi ve yabancı dil öğretiminde özel amaçlı okuma, yazma, dinleme ve konuşma becerisini geliştirme, akademik yazma öğretimi, başka bir ifadeyle üstsöylemin özel amaçlı olarak tüm beceri eğitimleriyle bağdaştırılması konusundaki çalışmaların Türkçede eksik olduğu görülmektedir. Türkçede hem metin türüne bağlı hem de metin türünden bağımsız olarak üstsöylem belirleyici listelerinin ortaya çıkarılması bu belirleyicilerin metin ve metin türü incelemeleri, akademik okuma, yazma, dinleme ve konuşma becerilerinin öğretimi gibi ortamlara aktarılmasına yardımcı olacaktır.

\section{4. Üstsöylem Çözümlemelerine Eleştirel Yaklaşımlar}

Hyland (2017), çalışmasında alanyazındaki birçok üstsöylem incelemesindeki çözümlemelerde birtakım sorunlar olduğunu belirtmiş ve bu çözümlemeleri yapan araştırmacıları eleştirmiştir. Araştırmacı, üstsöylemle ilgili çalışmalarda üstsöylem belirleyicisi olarak belirlenen birimlerle ve belirlenen üstsöylem belirleyicilerinin sınıflandırılmasıyla ilgili belirsizlikler bulunduğunu saptamıştır. Araştırmacının üstsöylem çözümlemeleriyle ilgili 
dikkat çektiği ilk belirsizlik, çalışmalarda üstsöylem ile önermesel içeriğin birbirine karıştırılmasıdır. Hyland'a göre bir metindeki bazı dilsel birimler yüzeysel okumayla üstsöylem olarak belirlenebilir. Ancak bu birimler ilgili bağlam içinde değerlendirildiğinde aslında önermesel içeriğe dâhildir. Benzer bir görüşe Vande Kopple (2012: 41) de dikkat çeker. Araştırmacı bir dilsel birimin bazı bağlamlarda üstsöylem bazı bağlamlarda ise önermesel öge olarak ortaya çıkabileceğini belirtir.

Yapılan üstsöylem çalışmalarındaki bir başka belirsizlik de üstsöylemin birçok farklı biçimde metnin yüzey yapısına yansıtılabilmesi nedeniyle ortaya çıkmaktadır. Bu farklı biçimler, bireysel sözcük seçiminden, yantümceye ya da tümcelere, hatta bir paragrafa kadar uzanan birçok farklı uzunlukta gerçekleşebilir (Hyland ve Tse, 2004: 157; Dafouz-Milne, 2008: 97; Hyland, 2017: 18). Dilsel birimlerin uzunluğu ya da kısalığı, büyük birimlerin içinde barındırdığı küçük birimler nedeniyle dikkat çekicidir (Hyland, 2017: 18). Sözgelimi bir öbek içinde birden fazla üstsöylem ögesi bulunabilir. İngilizcedeki "our purpose" (amacımız) ifadesi bir metin bölümü hakkında (burada metnin amacının verilmesi) bir bildirim olması nedeniyle bir çerçeve belirleyicisidir. Aynı zamanda bu birim içinde barındırdığı "our" ("-(I)mlz"/bizim) belirleyicisi ile kendinden söz etme üstsöylem belirleyicisi olarak da kullanılabilir. Böyle bir durumun sonucu olarak da alanyazındaki üstsöylem çözümlemelerinde en sık karşılaşılan sorun çözümlemelerde farklılıklar görülmesidir. Çünkü yukarıda verilen bir birim bazı çalışmalarda tek bir üstsöylem belirleyicisi, bazılarında ise iki farklı üstsöylem belirleyicisi olarak sınıflandırılabilmektedir. Buradan hareketle Türkçe gibi biçimbirimlerin oldukça işlevsel olduğu ve bir dilsel birimde çok sayıda biçimbirimin kullanılabildiği dillerde bu türden çok sayıda üstsöylem belirleyicinin bir arada kullanımı çözümleme sürecini etkileyen ve dikkat edilmesi gereken konulardan birisi olabilir.

Hyland'ın (2017: 18) çalışmasında dikkat çektiği bir diğer belirsizlik durumu çeşitli derlemlerde ve veritabanlarında aratılan üstsöylem listelerinden kaynaklanmaktadır. Benzer biçimde Ädel ve Mauranen (2010: 3) de araştırmacıların derlem temelli yaklaşımlarla birçok dilde ve farklı metin türlerinde daha önceden belirlenmiş üstsöylem listeleri yardımıyla üstsöylem belirleyicilerini saptamayı denediğini belirtir. Ädel ve Mauranen (2010: 3) ve Hyland (2017: 18) derlemde önceden belirlenen üstsöylem listelerinin taranmasını eleştirir, salt sayısal verilerin bir birimin üstsöylem olup olmadığını belirlemek ya da bir üstsöylemin bir ulama ait olup olmadığını sapta- 
mak için yeterli olmadığını, bu türden çalışmalarda birçok işlevin gözden kaçırıldığını belirtir.

Hyland (2017: 18-19) üstsöylem çalışmalarında karşılaşılan dördüncü belirsizliğin aynı ögenin birden çok üstsöylem ulamına ait olabilmesinden kaynaklandığını belirtmektedir. Araştırmacı bunun için ingilizceden "quite" (oldukça, çok, tam, tamamen, bütünüyle) sözcüğünü örnek olarak verir ve kullanımına bağlı olarak "quite good" (oldukça, çok, tamamen iyi) gibi ifadede bu sözcüğün kaçınma, "quite extraordinary" (oldukça, çok, bütünüyle olağandışı) gibi bir ifadede ise vurgulayıcı olarak değerlendirilebileceğini aktarır. Diller arasında farklılıklar olabileceği için aşağıda bu belirsizlikle ilgili Türkçe örnekler üzerinde durulmuştur:

Örnek: Bu çalışmamızdaki veriler...

Örnek: Ülkemizin güneyinde görülen...

Örnek'te kullanılan $\{-(\mathrm{I}) \mathrm{mlz}\}$ biçimbirimi birden çok yazar tarafından hazırlanan çalışmanın tüm yazarlarına gönderimde bulunan kendinden söz etme üstsöylem belirleyicisiyken diğer örnekteki kullanım metnin okurlarını söyleme dâhil eden katılım belirleyicidir? . Bu örnekler Hyland'ın (2017) verdiği "quite" örneğindekine benzer bir görünüm sunar.

Hyland (2017: 19), alanyazındaki çalışmalarda üstsöylemle ilgili bir diğer belirsizliğin üstsöylemin eksik tanımlanmasından kaynaklandığını belirtir. Bu eleştiri aslında Hyland'ın alanyazındaki üstsöylem modellerine yaptığı eleştiriye benzer bir eleştiridir. Buna göre üstsöylemi yalnızca metin aşamalarının etiketlenmesi, daha sonra gelen bilginin gösterilmesi ya da yazarın kendine gönderimde bulunması olarak algılamak ya da yalnızca yazarın ve konuşucunun söylediği şeye nasıl tepki verdiği, okurla bağlantı kurma yolları olarak belirlemek üstsöylem çalışmaları arasındaki farklılıkları oluşturmaktadır. Dolayısıyla üstsöylemi farklı tanımlamak da üstsöylem çözümlemeleri arasında hem niteliksel hem de niceliksel farklılıkların ortaya çıkmasına neden olmaktadır.

Hyland'ın (2017) dikkat çektiği, alanyazındaki üstsöylem çözümlemelerinde saptanan belirsizlikler göz önünde bulundurulduğunda Türkçe çalışmalarda da benzer birtakım belirsizliklerden söz edilebilir. Buna göre

\footnotetext{
${ }^{7}$ Birinci örnekte verilen dilsel kullanım birden çok yazar tarafından oluşturulan bir makaleye, ikinci örnekte verilen kullanım tek yazarlı, yazar ve olası okurların (burada makale Türkçe olduğu için okurların da Türkiye'den olacağı düşünülmüş olabilir) aynı ülkede yaşayan bireyler olduğu, yazar ve okurların bütün olarak değerlendirildiği ve alanyazında "kapsayıcı biz" (inclusive we) olarak söz edilen özelliğe gönderimde bulunmaktadır.
} 
özellikle biçimbirimlerin oldukça işlek olduğu bir dil olan Türkçede bu birimlerin üstsöylemsel işlevleri konusunda çalışmalarda birtakım farklılıklar görülmektedir. Bunun yanı sıra üstsöylem alanyazındaki çalışmaların genel olarak İngilizce metinler üzerine yapıldığı görülmektedir. İngilizcedeki üstsöylem listeleri incelendiğinde ${ }^{8}$ dilin yapısı gereği oluşturulan listeler sözcük listeleridir. Ancak Zeyrek'in (2002: 227) de dikkat çektiği gibi üstsöylem belirleyicileri farklı dilsel birimler olarak metnin yüzey yapısına yansıtılabilmektedir. Dolayısıyla Türkçedeki biçimbirimlerin de üstsöylemsel özellikler taşıması beklenen bir durumdur ve bu birimlerin de çalışmalara dâhil edilmesi gerekliliği ortaya çıkmaktadır. Biçimbirimlerin üstsöylem incelemelerinde dışarıda bırakılması hem üstsöylem betimlemelerinin ve açıklamalarının hem de bu özelliklerin başkaca ortamlara aktarılmasında sorunlar ortaya çıkarabilir.

\section{Sonuç}

Bu makale üstsöylem kavramının ne olduğunu, alanyazındaki üstsöylem sınıflandırmalarının nasıl olduğunu, Türkçe alanyazında üstsöylemle ilgili yapılan incelemelerin hangi noktalara odaklandığını ve üstsöylem çözümlemelerinde dikkat edilmesi gereken noktaların neler olduğuna yönelik genel bir bakış sunmaya çalışmıştır. Bu kapsamda üstsöylemin, önermesel anlamdan ayrı, önermesel anlama herhangi bir ekleme yapmayan ancak yazarın ya da konuşucunun önermesel anlamın nasıl anlaşılması gerektiğine, metnin tutarlıı̆̆ını sağlamaya yönelik, yazar ya da konuşucunun okur ya da dinleyiciyle etkileşime girmesini sağlayan dilsel birimler olduğu üzerinde durulmuştur. Üstsöylem belirleyicileri tek bir biçimbirimden bir paragrafa kadar ulaşabilen çeşitli uzunluklarda olabilir.

Alanyazında 1981 yılından 2005 yılına kadar çeşitli üstsöylem modelleri ortaya konmuştur. Bu modellerde özellikle Vande Kopple (1985) modeliyle birlikte kişilerarası özellikler de gündeme gelmiştir. Son olarak Hyland (2005) modelinde bilgi ve alıcı odaklı etkileşimler ortaya konmuş ve bu etkileşimlerin tamamı ister metne yönelik ister okur/konuşucuya yönelik olsun kişilerarası işlevler olarak belirlenmiştir. Modeller incelendiğinde bir önceki modelde yer alan ulamların uygulamada yetersiz kalması nedeniyle yeni ulamlamalar oluşturma, ulamları daraltma ya da genişletme yollarına gidilmiştir. Özellikle Hyland'ın (1998) üstsöylem modeli doğrudan akademik metinleri odak noktası yaptığı için türe özgü biçimlenişler daha net sapta-

\footnotetext{
8 Ingilizcede üstsöylem belirleyicilerinin en ayrıntılı listesi Hyland'ın (2005) Metadiscourse kitabının ekler bölümündedir.
} 
nabilmiştir. Hyland'ın (2005) modeli ise sınıflandırmada herhangi bir değişiklik yapmamış, buna karşın üstsöyleme nasıl bakılması gerektiği, üstsöylemin metinde üstlendiği görevler üzerine yeni bir bakış açısı kazandırmıştır.

Alanyazında farklı üstsöylem tanım ve modellerinin bulunması ve Swales'in (1993) ve Hyland'ın (2017) dikkati çektiği üstsöylemin uygulamada birtakım sorunlar ortaya çıkarması alandaki üstsöylem çözümlemelerinde de kendini göstermektedir. Bu bağlamda alanyazındaki çalışmalar da incelendiğinde birtakım belirsizliklerden söz edilebilir. Bu belirsizliklerin ortadan kaldırılmasıyla üstsöylem belirleyicinin saptanması ve başkaca ortamlarda kullanılması (örneğin metin ve metin türü incelemeleri, eğitimöğretim ortamları) olası olacaktır. Bu belirsizlikler, neyin üstsöylem neyin önerme içeriği olduğunun belirlemesinde, bir dilsel birimin içinde birden çok üstsöylem belirleyicisinin bulunabilmesi nedeniyle bazı belirleyicilerin saptanamamasında, bağlamın üstsöylem belirlemesinde ve sınıflandırmasında temel olması nedeniyle bağlam odaksız incelemeler yapıldığında, bir birimin farklı bağlamlarda farklı üstsöylemsel işlevler üstlenmesi nedeniyle sınıflandırma süreçlerinde ortaya çıkabilmektedir.

\section{Kaynakça}

Ädel, Annelie and Mauranen, Anna (2010). "Metadiscourse: Diverse and Divided Perspectives". Nordic Journal of English Studies, 9(2): 1-11.

Bayyurt, Yasemin (2017). "Üstsöylem ve Kültür Etkileşimi”. Dilbilim Çeviribi lim Yazıları. Ed. Neslihan Kansu Yetkiner ve Mehmet Şahin. Ankara: Anı Yayıncılık, 14-24.

Bayyurt, Yasemin ve Akbaş, Ekrem (2014). "Akademik Metinlerde Kaçınma ve Vurgulayıcı Ifadelerin Lisansüstü Öğrenciler Tarafından Algılanması ve Kullanılması". 27. Ulusal Dilbilim Kurultayı Bildirileri. Ed. S. Nalan Büyükkantarcıoğlu vd. Ankara: Hacettepe Üniversitesi, 72-79.

Crismore, Avon (1983). Metadiscourse: What is it and how is it used in School and Non-school Social Science Texts. Technical Report, No. 273. Illinois: University of Illinois.

Crismore, Avon et al. (1993). "Metadiscourse in Persuasive Writing: A Study of Texts Written by American and Finnish University Students". Written Communication, 10(1): 39-71. 
Çubukçu, Feryal (2017). "Revisiting Metadiscourse Markers of the Language Learners in Academic Writing". Revista Romaneasca Pentru Educatie Multidimensionala, 9(2): 36-47.

Dafouz-Milne, Emma (2008). "The Pragmatic Role of Textual and Interpersonal Metadiscourse Markers in the Construction and Attainment of Persuasion: a Cross-linguistic study of Newspaper Discourse". Journal of Pragmatics, 40:95-113.

Dağ-Tarcan, Özlem (2017). "Türkçe Bilimsel Metinlerde Etkileşimli Üstsöylem Belirleyicileri”. Ankara Üniversitesi Sosyal Bilimler Dergisi, 8(2): 176-194.

Dağ-Tarcan, Özlem (2019). Sosyal Bilimler Alanında Yazılan Türkçe Bilimsel Metinlerde Kullanılan Üstsöylem Belirleyicileri. Doktora Tezi. Ankara: Ankara Üniversitesi Sosyal Bilimler Enstitüsü.

Esmer, Elçin (2018). “Türkçeyi Yabancı Dil Olarak Öğrenen Öğrenciler Tarafından Üretilen İkna Metinlerinde Üstsöylem Belirleyicilerinin Kullanımı”. Dil Eğitimi ve Araştırmaları Dergisi, 4(3): 216-228.

Fidan, Özden ve Cem-Değer, Ayşen (2008). "Türkçe Yazılmış Dilbilim Araştırma Yazılarının Giriş Bölümlerindeki Alıntılama Örüntüleri”. 21. Ulusal Dilbilim Kurultay Bildirileri. Ed. Yeşim Aksan ve Mustafa Aksan. Mersin: Mersin Üniversitesi, 188-196.

Halliday, M. Alexander K. (2004). An Introduction to Functional Grammar. London: Arnold.

Hatipoğlu, Çiler and Algı, Sedef (2017). "Contextual and Pragmatic Functions of Modal Epistemic Hedges in Argumentative Paragraphs in Turkish". Metadiscourse in Written Genres: Uncovering Textual and Interactional Aspects of Texts. Ed. Çiler Hatipoğlu et al. Frankfurt am Main: Peter Lang, 85-108.

Hyland, Ken (1998a). "Persuasion and Context: The Pragmatics of Academic Metadiscourse". Journal of Pragmatics, 30: 437-455.

Hyland, Ken (1998b). Hedging in Scientific Research Articles. Amsterdam: Jon Benjamins.

Hyland, Ken (1998c). "Boosting, Hedging and the Negotiation of Academic Knowledge”. Text, 18(3): 349-382.

Hyland, Ken (2001). "Humble Servants of the Discipline? Self-Mention in Research Articles". English for Sprecific Purposes, 20: 207-226. 
Hyland, Ken (2005). Metadiscourse. Exploring Interaction in Writing. London: Continuum.

Hyland, Ken (2008a). "Persuasion, Interaction and the Construction of Knowledge: Representing Self and Others in Research Writing". International Journal of English Studies, 8(2): 1-23.

Hyland, Ken (2008b). "Disciplinary Voices. Interactions in Research Writing". English Text Construction, 1(1): 5-22.

Hyland, Ken (2010). "Metadiscourse: Mapping Interactions in Academic Writing". Nordic Journal of English Studies, 9(2): 125-143.

Hyland, Ken (2017). "Metadiscourse: What is it and Where is it going?" Journal of Pragmatics, 111: 16-29.

Hyland, Ken and Tse, Polly (2004). "Metadiscourse in Academic Writing: a Reappraisal”. Applied Linguistics, 25(2): 156-177.

Kan, M. Onur (2016). "The Use of Interactional Metadiscourse: A Comparison of Articles on Turkish Education and Literature". Kuram ve Uygulamada Eğitim Bilimleri, 16(5): 1639-1648.

Khedri, Mohsen et al. (2013). "An Exploration of Interactive Metadiscourse Markers in Academic Research Article Abstracts in Two Disciplines". Discourse Studies, 15(3): 319-331.

Kurudayıoğlu, Mehmet ve Çimen, Leyla (2020). "Yabancı Dil Olarak Türkçe Öğrenen Öğrencilerin Akademik Yazılarında Etkileşimli Üstsöylem Belirleyicilerinin Kullanımı". Uluslararası Toplum Araştırmaları Dergisi, 16(31): 3899-3923.

Martin, James R. and White, Peter R. R. (2005). The Language of Evaluation: Appraisal in English. New York: Palgrave Macmillan.

Önel, M. Ali (2020). Türkçe Eğitimi Alanında Yapılmış Yüksek Lisans Tezlerinde Kişilerarası Üstsöylem Belirleyicilerinin Betimlenmesi. Yüksek Lisans Tezi. Mersin: Mersin Üniversitesi Eğitim Bilimleri Enstitüsü.

Sarar-Kuzu, Tülay (2016). "Türkçe Öğretiminde Üstsöylem Belirleyicileri Aracılığıyla Dinleme Becerisinin Geliştirilmesi: Bir Etkinlik Modeli Önerisi”. Turkish Studies, 11(3): 1935-1952.

Şen, Ekin (2019). Bilimsel Makale Özetlerinde Üstsöylem Belirleyicinin incelenmesi. Doktora Tezi. İzmir: Dokuz Eylül Üniversitesi Sosyal Bilimler Enstitüsü. 
Şen, Ekin (2020). 'Makale Özetlerinde ‘Ben' ve ‘Biz’: Bir Üstsöylem Çözümlemesi”. International Journal of Language Academy, 8(1):62-72.

Şenöz-Ayata, Canan (2014). Bilimsel Metin Üretimi. İstanbul: Papatya Yayıncılık.

Swales, John M. (1993). Genre Analysis: English in Academic and Research Settings. Cambridge: Cambridge University Press.

Thomas, Sarah and Hawes, Thomas P. (1994). "Reporting Verbs in Medical Journal Articles”. English for Specific Purposes, 13(2): 129-148.

Thompson, Geoff (2001). "Interaction in Academic Writing: Learning to Argue with the Reader". Applied Linguistics, 22(1): 58-78.

Uluçam-Wegmann, A. Işıl (2018). "Birinci ve İkinci Dilde Metin Türüne Özgü Yazma: Benzerlikler, Farklılıklar ve Etkileşimler”. Türkçenin EğitimiÖğretiminde Kuramsal ve Uygulamalı Çalışmalar-10. Ed. N. Engin Uzun ve N. E. ve B. Umut Bozkurt. İstanbul: Okan Üniversitesi Yayınları, 37-74.

Uluçay, Çiğdem and Hatipoğlu, Çiler (2017). "Causal Markers in Turkish Cause Paragraphs". Metadiscourse in Written Genres: Uncovering Textual and Interactional Aspects of Texts. Ed. Çiler Hatipoğlu et al. Frankfurt am Main: Peter Lang, 223-249.

Uzun, Leyla (2002). "Dilbilim Alanında Türkçe Yazılan Araştırma Yazılarında Metin Dünyasına iliş̧kin Düzenlemeler”. Türkçede Bilgi Yapısı ve Bilimsel Metinler. Ed. Leyla Uzun ve Emel Huber. Essen: Die Blaue Eule, 203-224.

Uzun, Leyla (2006). "Bilimsel Söylem ve Özellikleri”. Sosyal Bilimlerde Süreli Yayıncılık 1, Ulusal Kurultay Bildirileri. Ed. Kasım Karakütük. Ankara: TÜBiTAK Yayınları, 133-140.

Vande Kopple, William J. (1985). "Some Exploratory Discourse on Metadiscourse". College Composition and Communication, 36(1): 82-93.

Vande Kopple, William J. (2012). "The Importance of Studying Metadiscourse". Applied Research in English, 1(2): 37-44.

Williams, Joseph M. (1990). Style: Toward Clarity and Grace. Chicago: University of Chicago Press.

Williams, Joseph M. (2013). Style: Lessons in Clarity and Grace. New Jersey: Pearson.

Zeyrek, Deniz (2002). "Psikoloji Makalelerinde Üstsöylem Belirleyicileri". Türkçede Bilgi Yapısı ve Bilimsel Metinler. Ed. Leyla Uzun ve Emel Huber. Essen: Die Blaue Eule, 225-242. 
"COPE-Dergi Editörleri iç̧in Davranış Kuralları ve En İyi Uygulama ilkeleri” çerçevesinde aşağıdaki beyanlara yer verilmiştir:

Yazarın Notu: Kavram Türkçe alanyazında da çalışımakta ancak özellikle üstsöylem modelleri ile ilgili bu kadar kapsamlı çalışma bulunmamaktadır. Çalışmada birçok kavramın Türkçe karşılıkları yeni olduğu için kavramlar italik yazılmış, okurların kavramla ilgili oluşabilecek sorularını önceden yanıtlamak için parantez içinde özgün biçimi İngilizce olarak verilmiştir.

Etik Kurul Belgesi: Bu çalışma için etik kurul belgesi gerekmemektedir.

Çıkar Çatışması Beyanı: Bu makalenin araştırması, yazarlığı veya yayınlanmasıyla ilgili olarak yazarın potansiyel bir çıkar çatışması yoktur.

The following statements are made in the framework of "COPE-Code of Conduct and Best Practices Guidelines for Journal Editors":

Author's Note: The concept is also studied in the Turkish literature, but there is no such comprehensive study on meta-discourse models. Since the Turkish equivalents of many concepts are new in the study, the concepts are written in italics, and the original form is given in English in parentheses in order to answer the readers' questions about the concept beforehand.

Ethics Committee Approval: Ethics committee approval is not required for this study.

Declaration of Conflicting Interests: The author has no potential conflict of interest regarding research, authorship or publication of this article. 